\title{
Sprawozdanie z dziatalności Koła Naukowego studentów Międzyuczelnianego Instytutu Muzyki Kościelnej w Krakowie „Congaudeant”
}

Koło Naukowe „Congaudeant”, działające przy Międzyuczelnianym Instytucie Muzyki Kościelnej, od początku istnienia Instytutu propaguje, rozpowszechnia i pogłębia wiedzę o muzyce kościelnej, a także muzyce organowej, chóralnej czy śpiewie gregoriańskim. Cele te skrupulatnie realizowane są przez studentów poprzez organizowanie koncertów, warsztatów czy nabożeństw z udziałem scholi gregoriańskiej.

Także w ostatnim czasie Koło, którego opiekunem jest s. dr hab. Susi Ferfoglia, prof. UPJPII, zorganizowało kilka ciekawych wydarzeń. Należy do nich zaliczyć wyjazd, który odbył się 23 maja 2019 roku, do Olkusza - historycznego miasta, którego perłą jest bazylika św. Andrzeja z przełomu XIII i XIV wieku. W tym to kościele, razem z naszymi kolegami - studentami Akademii Muzycznej w Poznaniu, mogliśmy obejrzeć najstarsze organy piszczałkowe w Polsce z 1623 roku, autorstwa organmistrza Hansa Hummla, które w minionych latach przeszły żmudny proces renowacji. Szczegółową historię instrumentu, połączoną z prezentacją wszystkich charakterystycznych głosów przedstawił dr Filip Presseisen - pracownik UPJPII oraz MIMK w Krakowie. Każdy z nas mógł usiąść przy stole gry i poczuć się jak prawdziwy, renesansowy muzyk. Na zakończenie, o godz. 18.00 czynnie uczestniczyliśmy w Mszy św., wykonując śpiew gregoriański oraz utwory wielogłosowe. Mszę św. w naszej intencji odprawił ks. dr hab. Mariusz Białkowski, wykładowca poznańskiej AM, który przyjechał wraz ze studentami. Nazajutrz udaliśmy się do Katowic, rozpoczynając kolejny dzień od wizyty w kościele ewangelicko-augsburskim Zmartwychwstania Pańskiego, gdzie Filip Presseisen dokonał prezentacji świeżo odrestaurowanych organów Sauera, na których później każdy z nas miał okazję zagrać m.in. dzieła Maxa Regera, grającego i komponującego na instrumentach tej firmy. Naszą wizytę w Katowicach zakończyliśmy wspólnym obiadem w holu Akademii Muzycznej oraz wizytą w Muzeum Organów, po którym oprowadził nas dr Stanisław Pielczyk. 
Kolejnym wydarzeniem był fantastyczny wyjazd do Łodzi, który odbył się w dniach 20-21 listopada 2019 roku, na zaproszenie dr. hab. Krzysztofa Urbaniaka, pracownika Katedry Organów, Klawesynu i Muzyki Dawnej w Akademii Muzycznej. Oprowadził on nas szczegółowo po pięknym, zabytkowym budynku Akademii z początku XX wieku, a także zaprezentował znajdujące się tam instrumenty piszczałkowe, jak. np. w Sali Kameralnej, gdzie wybudowano kopię XVIII-wiecznego instrumentu barokowego. Oprócz instrumentów akademickich posłuchaliśmy brzmienia romantycznych organów Riegera w kościele ewangelicko-augsburskim św. Mateusza oraz wspaniałych symfonicznych i barokowych organów znajdujących się w Filharmonii Łódzkiej. Wszystkie te instrumenty z niezwykłą dokładnością prezentował nam Krzysztof Urbaniak. Na zakończenie wyjazdu w podziemiach archikatedry uczestniczyliśmy w Mszy św., podczas której wykonaliśmy śpiewy gregoriańskie. Odprawił ją dla nas absolwent naszego Instytutu, ks. Piotr Przybysz, wikariusz parafii archikatedralnej. W tym dwudniowym wydarzeniu uczestniczyli również nasi przyjaciele z Akademii Muzycznej w Poznaniu.

W nowym roku akademickim zainaugurowaliśmy Msze św. w intencji studentów i pracowników MIMK. Oprócz modlitwy ważne miejsce podczas takich celebracji zajmuje śpiew gregoriański, a - jak podkreśla s. Susi Ferfoglia prowadząca w naszym Instytucie wykłady z historii i praktyki śpiewu gregoriańskiego - nic bardziej nie oddaje charakteru tych śpiewów niż Eucharystia. Pierwsza Msza św. odbyła się 28 października pod przewodnictwem ks. abp. Marka Jędraszewskiego w kaplicy kurii krakowskiej, kolejna 18 listopada w kościele bł. Anieli Salawy w ramach Dni Muzyki Kościelnej, a następna 9 grudnia w kościele MB Dobrej Rady, który sąsiaduje z budynkiem Instytutu, na zakończenie Sesji Naukowej Polska solowa muzyka na okres Adwentu. Ważnym wydarzeniem były także nieszpory łacińskie, które śpiewaliśmy w kościele św. Krzyża 9 marca, a które odprawił proboszcz i zarazem duszpasterz środowisk twórczych archidiecezji krakowskiej ks. dr Dariusz Guziak. Było to niesamowite doświadczenie zobaczyć w zwykłym dniu tygodnia prawie pełen kościół chcących duchowo przeżyć to wydarzenie.

Zarówno Msze św., jak i nieszpory od roku akademickiego 2019/2020 stały się nieodłącznym elementem naszej edukacji w Krakowie, co zgodnie przyznają wszyscy studenci MIMK. Dlatego tym bardziej chętnie zostanie podjęty nowy rok akademicki 2020/2021, podczas którego ta inicjatywa będzie stanowić dla nas duchowe umocnienie. Studenci serdecznie dziękują s. Susi za perfekcyjne przygotowanie śpiewów mszalnych oraz za organizację wyjazdów naukowych. Oby więcej takich przedsięwzięć! 